\title{
Folk classification and traditional uses of Cyperus esculentus, a neglected and underutilized species in Benin
}

\section{VIDÉDJI NAÉSSÉ ADJAHOSSOU ${ }^{1, \vartheta}$, DOSSOU SEBLODO JUDES CHARLEMAGNE GBEMAVO ${ }^{2,3}$, SAMUEL ABIDJA ${ }^{2}$, JUDICAËL LALY ${ }^{2}$, AHODONISSOU ANICET GBAGUIDI ${ }^{1}$, ALEXANDRE DANSI ANAGONOU ${ }^{1}$}

${ }^{1}$ Laboratoire des Biotechnologies, Ressources Génétiques et Amélioration des Espèces Animale et Végétale (BIORAVE), Ecole Nationale Supérieure des Biosciences et Biotechnologies Appliquées (ENSBBA) de Dassa Zoume, Université Nationale des Sciences, Technologies, Ingénierie et Mathématiques (UNSTIM). BP 14 Dassa Zoumé, Bénin. Tel.: +229-97685671. `email: vidnae@yahoo.fr,

${ }^{2}$ Unité de Biostatistique et de Modélisation (UBM), Ecole Nationale Supérieure des Biosciences et Biotechnologies Appliquées (ENSBBA), Université Nationale des Sciences, Technologies, Ingénierie et Mathématiques (UNSTIM). BP 14 Dassa Zoumé, Bénin

${ }^{3}$ Laboratoire de Biomathématiques et d'Estimations Forestières, Faculté des Sciences Agronomiques, Université d'Abomey-Calavi. 04, BP 1525, Cotonou, Bénin

Manuscript received: 19 May 2021. Revision accepted: 27 June 2021.

\begin{abstract}
Adjahossou VN, Gbemavo DSJC, Abidja S, Laly J, Gbaguidi AA, Anagonou AD. 2021. Folk classification and traditional uses of Cyperus esculentus, a neglected and underutilized species in Benin. Biodiversitas 22: 2972-2979. The sweet pea or tigernut (Cyperus esculentus L.) has very high potential to be developed but is considered a neglected and underutilized plant in Benin. The current study aims to investigate the indigenous knowledge related to local diversity, production and uses of various landrace types of tigernut grown in its production areas in Benin. Using Participatory Research Appraisal (PRA) method, we surveyed 113 tigernut farmers in different regions of production in Atacora Department, Benin. Univariate statistics were performed to describe and compare tigernut farmers' responses on botanical and agronomic criteria. We found that the tigernut farmers in the studied area distinguished three landraces of $C$. esculentus. Two landrace types produced yellow-skinned tubers and the other produced black-skinned tubers. Economic value, agromorphological traits and organoleptic quality were the criteria considered by the farmers when choosing the type of landrace to cultivate. According to the farmers, the attacks of the tubers by earthworms and termites constituted the main constraints of the production of tigernut. Local people used the species mainly for food, while small proportion was for medicine (e.g., for aphrodisiac) and soil fertilization purposes. This study implies that $C$. esculentus in Benin deserves better attention to be conserved and developed.
\end{abstract}

Keywords: Biotechnology, Cyperus esculentus, local diversity, traditional uses

\section{INTRODUCTION}

Benin Republic is a country with an economy that is mainly supported by agriculture sector in which $70 \%$ of the people work in this sector (Gbemavo 2014). Among various agricultural commodities in Benin, sweet pea or tigernut (Cyperus esculentus L.), belonging to Cyperaceae family, is one of crops species cultivated by farmers in the country. In Africa, tigernut was introduced in Niger during the colonization period about a century ago, and currently, there are two morphotypes of tigernut, including small nutsedge and big nutsedge (Bori et al., 2018). Tigernut is now grown mainly in the west (Bado et al. 2015) as well as in Benin but on a small scale.

Cultivated mainly for its tubers, tigernut is utilized to produce food (Adomou et al. 2012), commercial products (Warouma 2013), medicinal materials (Ambarwati et al. 2019), and so on. In Niger, the crop development had led to an increase in national production with an estimate up to 100000 tons (Warouma et al. 2013). In this country, twothird of the tigernut production is now exported to Nigeria, another big nutgrass-consuming country (Almou Mani 2008). Bori et al. (2018) estimated that the average income per hectare for a producer can reach 823.40 USD $(452,461$
West African CFA Franc).

In terms of food, its tubers are consumed in raw, roasted, dried and cooked forms (Oladele and Aina 2007; Bori et al. 2018). These tubers are also processed into a juice called "nono aya" in Niger (Bori et al. 2018), alcoholic drinks of kings in Ivory Coast (Ban-Koffi et al. 2005), a refreshing drink called "Horchata De Chufas" in Nigeria as well as to make oil, soap and starch (Oladele and Aina 2007; Maduka and Ire 2018). In addition, the tubers are milled in flour and used as a thickener, potatoes and seeds mixed with water (Bado et al. 2015) or mixed with sugar to prepare biscuits called "dakoua" (Bori et al. 2018).

According to Ban-Koffi et al. (2005), tigernut is a great source of macronutrients (i.e., starch, fat and sugar) and minerals. Moreover, the proportions of proteins and minerals in tubers are higher than those of some staple foods consumed from Ivory Coast and elsewhere in Africa. In Benin, tigernut has been listed among the medicinal plants sold in the Abomey-Calavi market (Adomou et al. 2012). It is used to treat lethargy, indigestion, diarrhea, dysentery, sexual infertility and excessive thirst (Adejuyitan 2011). In Indonesia, its close relative (i.e., Cyperus rotundus L) is shown to have biological and pharmacological activities and it has been traditionally 
used to treat various diseases and as remedy system despite being considered as weed (Nurcahyani et al. (2017).

Despite these great potentials, tigernut remains a neglected and underutilized plant in the world (Bado et al. 2015) and in Benin in particular (Dansi et al. 2012). Indeed, in Benin, few studies carried out on tigernut have only mentioned the species among many others and have mainly reported its presence in the country (Akoègninou et al. 2006) and its current status as a neglected species and underutilized (Dansi et al. 2012). Therefore, it is necessary to fill the knowledge gap on this species in order to contribute to its improvement and development for higher commercial uses. The current study aims to investigate the indigenous knowledge related to local diversity, production and uses of various landrace types of tigernut grown in its production areas in Benin. The results of this study will guide studies on the genetic diversity of this crop and help formulate sustainable promotion and conservation strategies, both in-situ and ex-situ.

\section{MATERIAL AND METHODS}

\section{Study area and period}

This study was conducted in the Atacora Department located in northwestern of Benin (Figure 1). According to INSAE (2016-a), Atacora is the third department in Benin with an area of $20.499 \mathrm{~km}^{2}$ after Alibori $\left(26.242 \mathrm{~km}^{2}\right.$ ) and Borgou $\left(25.856 \mathrm{~km}^{2}\right)$. Its landform is characterized by a large chain of $700 \mathrm{~m}$ altitude on average, whose summit is located at Boukombe $(835 \mathrm{~m})$ called "chain Atacora", representing the water tower from which flow the major rivers of the Benin and Togo (Ouémé, Mono, Mékrou, Pendjari, Kérou or Kouamongou). The climate is Sudanese with an average annual rainfall between $800 \mathrm{~mm}$ to $1200 \mathrm{~mm}$. There are three main soil types in this department: tropical ferruginous soils, ferralitic soils, and light hydromorphic soils. The vegetation is characterized mainly by a savannah dotted with some Shea and Locust bean trees. The department had 772,262 inhabitants (INSAE, 2016-b) with a density of 26.8 inhabitants per $\mathrm{km}^{2}$. The main ethnic groups are Gua or Otamari and related (59.3\%), Bariba and related $(19.0 \%)$, and Peulh or Peul (12.5\%). Regarding the economic activities of the department, the people devote their efforts mainly to agricultural activities (74\%) but also to fishing, hunting, trade, catering, and lodging. The present study are conducted in 2017.

\section{Species description}

This study is focused on the landraces of C. esculentus produced by local framers in Atacora region. The general description of the species was based on existing references (e.g., Hochstrasser 2015; Jansen 1971; Lorougnon 1969; Dodet 2006) and can be explained as follow. C. esculentus is a perennial herb that is $30-70 \mathrm{~cm}$ tall. Its young rhizome is white, fleshy, with knots and internodes and an apical meristem covered with sharp tractive foliage scales. This organ exists under two types: the deep oblique rhizomes whose apical meristem differentiates a tuber and the horizontal superficial rhizomes which give a new basal bulb carrying chlorophyllin leaves.

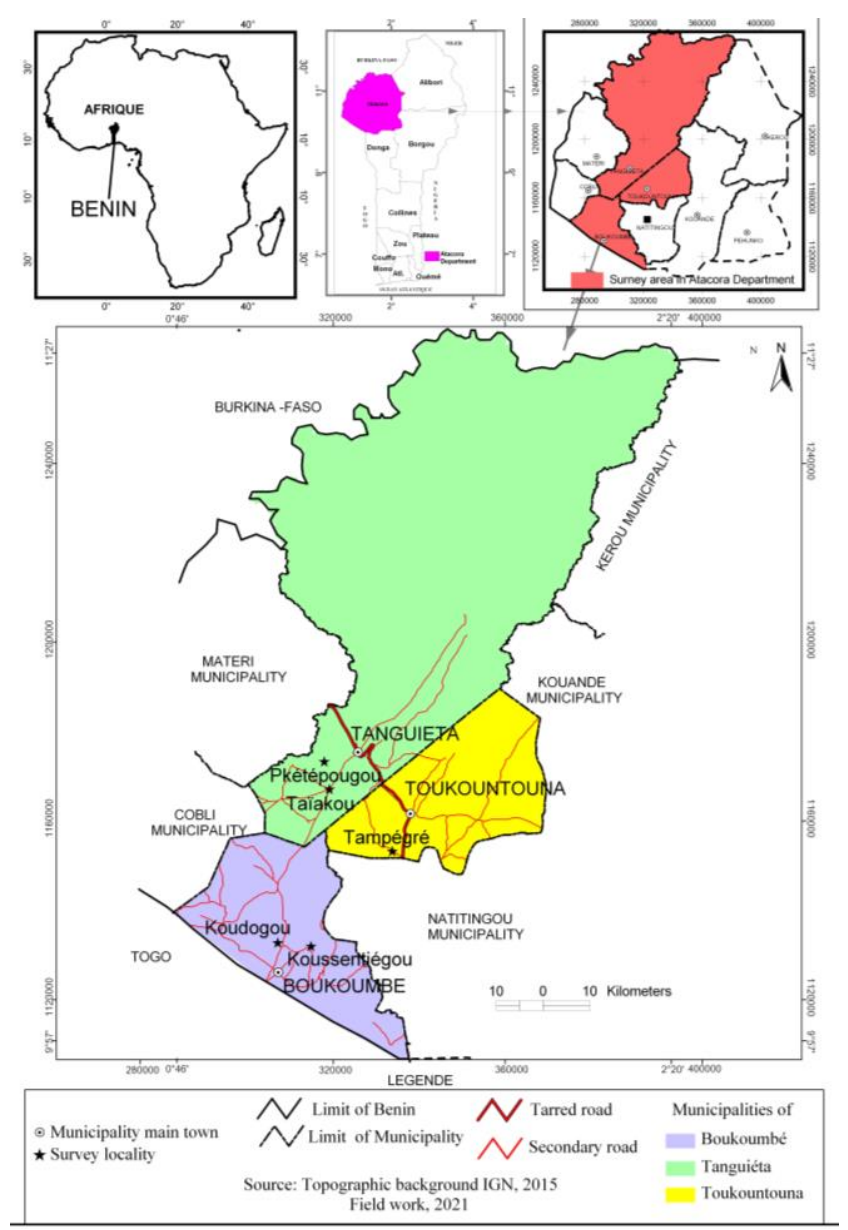

Figure 1. Map of the study area in the Atacora Department, Benin and geographical position of the surveyed villages

The roots are fasciculate, simple, threadlike and fibrous, and can penetrate more than one meter deep. They originate in the endodermal tissues of the tuber and basal bulb, and then cross the cortical and epidermal zones indifferently. As for the tubers, they are white before the end of maturity, then brown-chestnuts and finally almost black. The stem is triangular glabrous full, without knot. The leaves are light green, 5-10 mm wide, shorter than the stem, in 3 groups. In addition, they are almost all basal, with sheaths welded edges, flat, and their limb is traversed by a very strong network, tight small longitudinal ribs. In the end, the inflorescence is a compound or almost simple umbel. The racemes are more or less elongated depending on the Type, but always pale yellow or dark brown and contain 6 to 30 flowers.

\section{Sampling and data collection}

A preliminary exploratory phase helped to identify Atacora Department as the excellent tigernut cultivation area in Benin Republic. Afterward, five sweet pea cultivation regions were chosen according to the criteria of relative importance of $C$. esculentus cultivation, ethnic diversity, and cultural importance of the species (Laly et al. 2019). These districts were Tempégré, Taiacou, Kpeteporikou, Koussetiegou and Koudogou. The same region choice criteria were used to select two localities in 
each district. The snowball method (Naderifar and al., 2017) was used to list the crop producers in each sample locality and a random selection of 30 farmers was made. In the case of the total number of tigernut farmers is less than 30 in one locality, all producers were systematically surveyed. A total of 113 tigernut farmers were surveyed. Individual surveys and focus groups were used to collect the data. For the focus groups survey, the Participatory Research Appraisal (PRA) method (Laly et al. 2019) was used. The interviews were conducted with the help of translators in each locality. The data collected were related to the socio-economic characteristics of producers, agricultural practices, production constraints, existing landrace types (diversity, origin, traditional description, and classification), and traditional use.

\section{Data analysis}

The variables collected on producers of $C$. esculentus were qualitative nominal (commune, sex, ethnic), qualitative ordinal (educational level) and continuous quantitative (age). Similarly, variables collected on farmers' choice criteria, agricultural practices, production constraints and uses were qualitative. Descriptive statistics (percent, mean, standard deviation) were used to describe the producers and their responses. The bar charts of the producers concerning the different landrace types were graphed according to the production district, ethnic groups and sex in order to assess for each variable (commune, ethnicity, sex), the landrace types mostly cultivated. The relation between each of the three variables (commune, ethnicity and sex) and the landrace types was tested using Fisher test and chi-square independence test. All data analyses were performed using R software (R Core Team 2017).

\section{RESULTS AND DISCUSSION}

\section{Characteristic of the producers of Cyperus esculentus}

Most of $C$. esculentus producers surveyed were men $(53.10 \%)$. They belong to five ethnic groups (Betamaribè, Couteni, Ditammari, Nateni, and Waama) with a dominance of Ditammari (44.25\%). These producers had a very low education level. Most of them (73. 45\%) have never been to school, only $18.58 \%$ have reached secondary school and the remaining $(7.96 \%)$ have been to primary school. The structure of the age data showed that $31.85 \%$ of the respondents were young (Age < 30 years); $62.83 \%$ were adults (30 years < Age < 60 years) and only $5.30 \%$ were old people (Age $>60$ years) with an average equal to 36 years.

\section{Landrace taxonomy and diversity of Cyperus esculentus}

In Atacora Department, $C$. esculentus has been named by a local name according to the different ethnic groups (Table 1). Cyperus esculentus is called Tchesia (Betamaribè and Waama), Sakapouanga (Couteni), Essantamoila (Ditammari), yanantchapouanla (Ditammari) and Yassiponga (Nateni). The meaning of the different local names recorded was almost the same and was related to the "sweet taste" of the species tubers. In terms of diversity, the producers distinguished only three landrace types based on botanical traits, mainly the color of tuber peel and the presence or absence of inflorescence (Table 2). According to the producers, two landrace types (Type A and Type B) produced yellow-skinned tubers, and the third (Type C) produced black-skinned tubers (Figure 2). The landrace Type A produced inflorescences while that B and $\mathrm{C}$ had no inflorescence. Studies showed that these different landrace types didn't have specific or distinctive names. According to most producers in all groups surveyed, the three landrace types would come from either Togo or Burkina Faso except a few producers who said that Type A and Type B would come from Niger.

\section{Farmer's criteria when choosing Cyperus esculentus landrace varieties}

In total, six criteria were defined by the farmers when choosing the preferred $C$. esculentus variety to cultivate which can be grouped into three, namely economic aspect (e.g., high market value), agro-morphological aspect (e.g. good yield, large tuber) and organoleptic aspect (e.g., taste) (Table 3). Although the importance of the criteria varied according to landrace types, the general trend was the same with a few variations (Table 3). Producers selected and cultivated Type A mainly due to the sweet taste of its tubers $(29.20 \%)$ and its high market value $(6.19 \%)$, while landrace Type B was grown mainly because of its taste very sweet $(25.66 \%)$, good yield $(10.61 \%)$, large tubers $(3.50 \%)$ and high market value $(6.19 \%)$. The landrace Type $\mathrm{C}$ was mainly cultivated because of its moderately sweet tubers (13.27\%) and its good yield (6.19\%).

Table 1. The local name of Cyperus esculentus in different ethnic groups and its meaning in local terminology

\begin{tabular}{lll}
\hline Ethnic group & Generic names & Meaning \\
\hline Couténi & Sakapouanga & Sweet tuber \\
Naténi & Yassipouanga & Tubers sucked water \\
Ditammari & Essantamoila, & Sweet tuber \\
& yanantchapouanla & \\
Waama & Tchesia & Sweet tuber \\
Bétémaribè & Tchesia & - \\
\hline
\end{tabular}

Table 2. Morphological characteristics of the three Cyperus esculentus landraces types collected in this study

\begin{tabular}{|c|c|c|c|}
\hline Organs & Type A & Type B & Type C \\
\hline Tuber & $\begin{array}{l}\text { Light yellow *, } \\
\text { round or } \\
\text { elongated and } \\
\text { hairy }\end{array}$ & $\begin{array}{l}\text { Brown yellow *, } \\
\text { round or elongated } \\
\text { and hairy }\end{array}$ & $\begin{array}{l}\text { Black*, } \\
\text { round or } \\
\text { elongated } \\
\text { and hairy }\end{array}$ \\
\hline Root & Yellow & Yellow & Black \\
\hline Leaf & Gloomy green & Green & Green \\
\hline Stem & $\begin{array}{l}\text { Green and } \\
\text { cylindrical }\end{array}$ & Green & Green \\
\hline Inflorescence & Present $*($ cream $)$ & Absent & Absent \\
\hline
\end{tabular}

Note: * designates the main botanical trait of distinction 


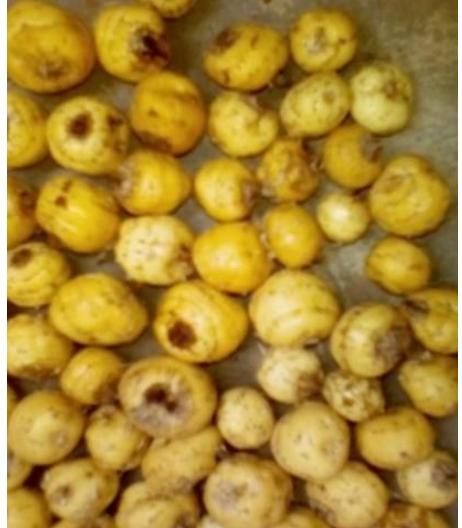

Type A

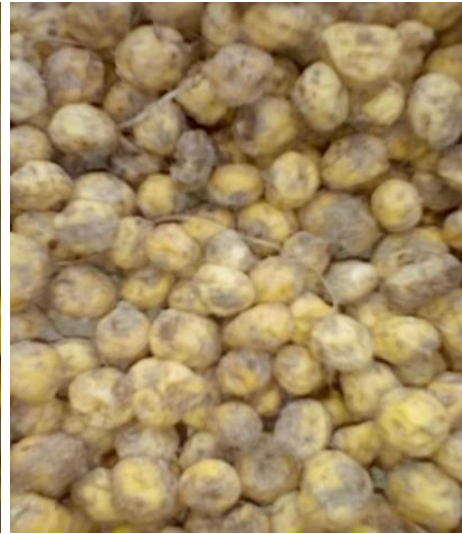

Type B

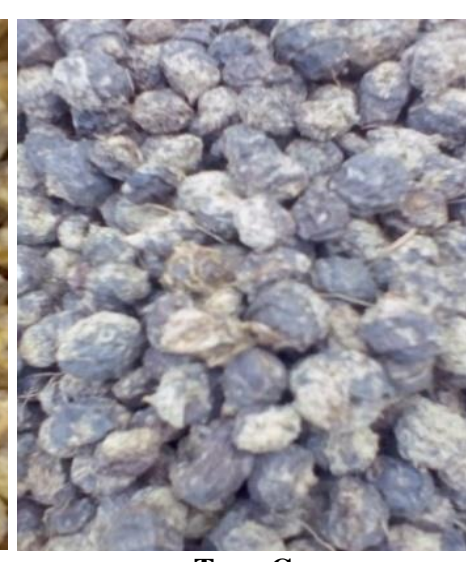

Type C

Figure 2. Three landrace types of Cyperus esculentus grown in the studied area: Type A: light yellow variety, Type B: brown-yellow variety and Type C: black variety (Photographs: Abidja 2017)

Table 3. Famer's criteria when choosing landraces types of Cyperus esculentus and its level of importance

\begin{tabular}{|c|c|c|c|}
\hline \multirow[t]{2}{*}{ Famer's criteria } & \multicolumn{3}{|c|}{$\begin{array}{c}\text { Level of importance (\% of } \\
\text { respondents) }\end{array}$} \\
\hline & Type A & Type B & Type C \\
\hline \multicolumn{4}{|l|}{ Agro-morphological criteria } \\
\hline Good performance & 0.88 & 10.61 & 6.19 \\
\hline Big tuber & 2.65 & 3.50 & 2.65 \\
\hline \multicolumn{4}{|l|}{ Organoleptic criteria } \\
\hline Very sweet taste & 15.04 & 25.66 & 0 \\
\hline Less sweet taste & 0 & 7.6 & 13.27 \\
\hline Sweet taste & 29.20 & 2.65 & 6.19 \\
\hline \multicolumn{4}{|l|}{ Economic criteria } \\
\hline Strong market value of tubers & 6.19 & 6.19 & 2.65 \\
\hline
\end{tabular}

\section{Landrace types of $C$. esculentus across districts, ethnicities and genders}

Figure 3 presents different types of C. esculentus landrace cultivated across districts, ethnicities and genders. The result showed that in Boukombé district, two landrace types of $C$. esculentus (Type B and Type C) were cultivated with a predominance of Type B (Figure 3.A). In the two other districts (Tanguieta and Toucountouna), all three landrace types were cultivated with a predominance of Type A and Type B, respectively. When considering ethnic groups (Figure 3.B), Betamaribè cultivated only one landrace type (Type C), unlike Couténi and Ditammari, which cultivated two landrace types (Type B and Type C) with a predominance of Type B. Nateni also cultivated two landrace types (Type A and Type B) with a predominance of Type B. Waama cultivated all three landrace types dominated by Type A. In terms of gender, men and women had all three landrace types but the landrace Type B was more cultivated by both sex than the others.

The results of Fisher's exact test showed that the type of landrace cultivated depends on the region of provenance of farmers $(\mathrm{P}<0.05)$. Moreover, the result of the Chi-square independence test showed that the choice of landrace types did not depend on sex $(\chi 2=3.46, \mathrm{P}=0.17$, ddl $=2)$.

\section{Agricultural practices}

In Atacora Department, $C$. esculentus was cultivated in marginal lands, mountainous zones, and fertile sandy soils (Figure 4.A). In most of the fields visited, C. esculentus was cultivated as monoculture, while few were intercropped with Abelmoschus esculentus also named okra (Figure 4.B). In the latter case, C. esculentus was the main crop. According to the surveyed farmers, the sowing time of $C$. esculentus varied between April and June of each year and depended on the beginning of the rainy season. In addition, the production cycle varied according to the landrace types. The landrace types A and B exhibited three months of production cycle, unlike Type $\mathrm{C}$ with a production cycle that extended until four months.

The field visits revealed that $C$. esculentus was produced in small areas and these latter varied according to producers and landrace types. In fact, the average cultivated areas of Type A, Type B, and Type C respectively were $0.22,0.47$ and 0.14 hectares. It appears that Type $\mathrm{B}$ occupied more areas contrary to Type $\mathrm{C}$ which occupied less area. According to surveyed producers, $C$. esculentus yield could vary between 0.5 tons/hectare and 8 tons/hectare with average equal to 3.16 tons/hectare. The yields varied also following landrace types of which the average values are 1.91, 3.09 and 1.86 tons/hectare respectively for Type $\mathrm{A}$, Type $\mathrm{B}$, and Type $\mathrm{C}$.

\section{Production constraints}

The production constraints of $C$. esculentus reported by the producers were mainly caused by biotic factors (Table 4). According to the farmers, the attacks of the tubers by earthworms $(53.92 \%$ of the respondents) and termites (38.05\% of the respondents) constituted the main biotic constraints of productions. According to focus groups, the major non-biological constraint in $C$. esculentus production was the lack of markets for sale. 


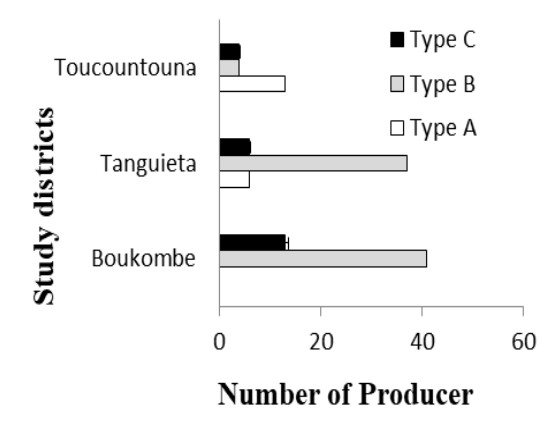

A

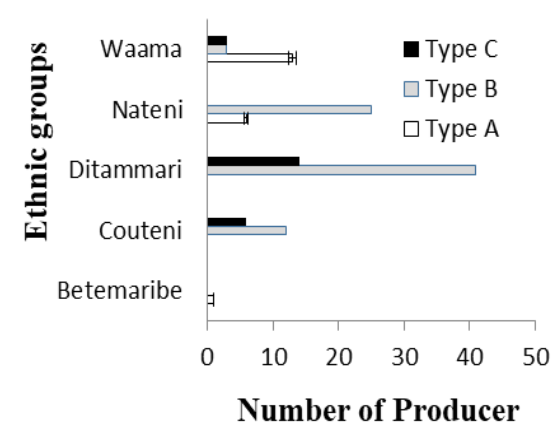

B

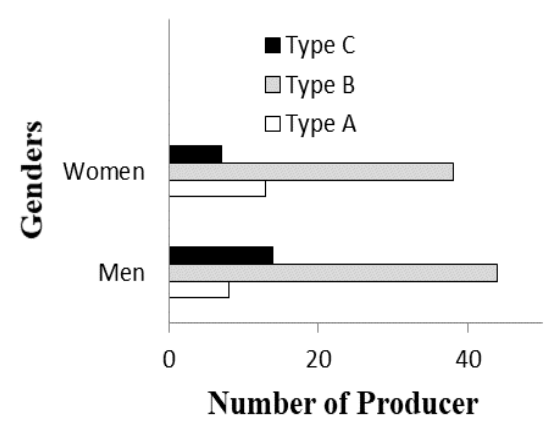

C

Figure 3. Bar graph showing different landrace types cultivated and number of farmers across: A. Districts; B. Ethnic groups; C. Genders

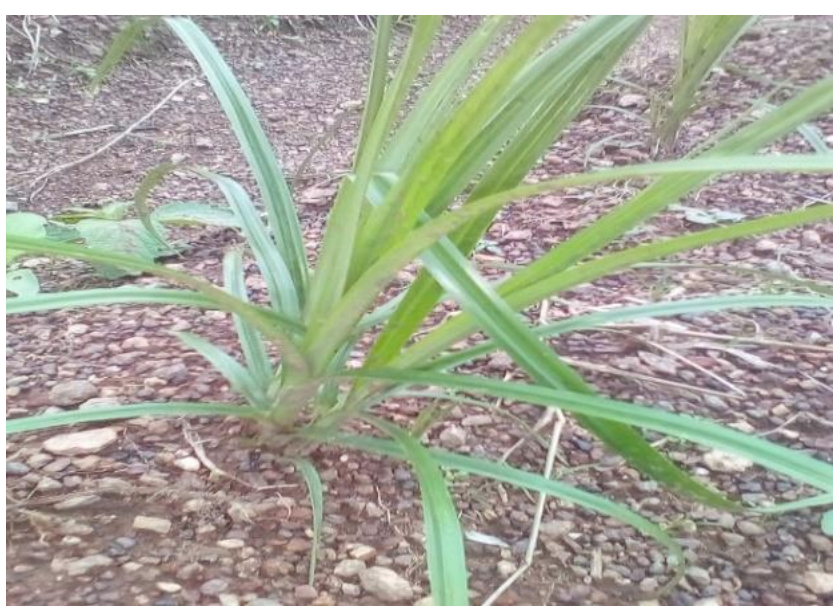

A

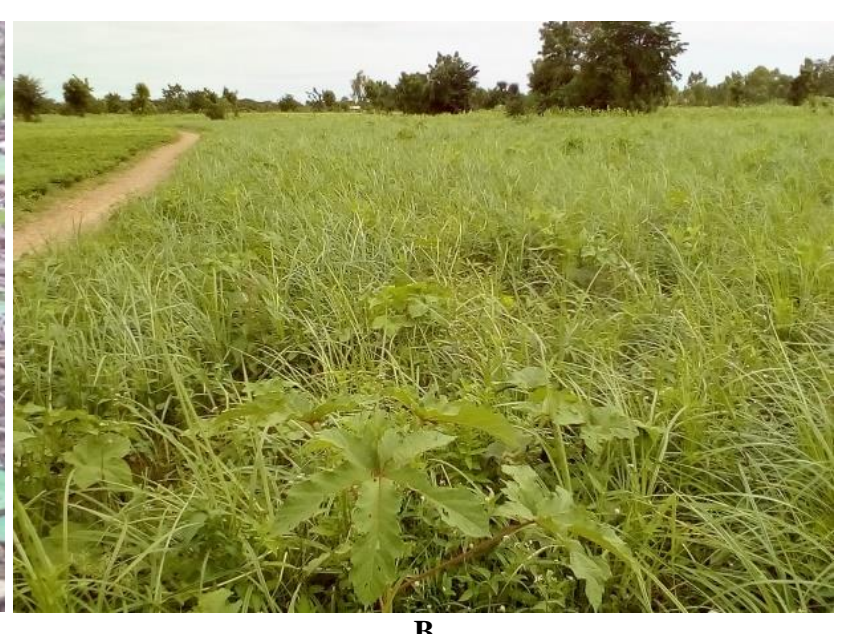

B

Figure 4. Agricultural practices of Cyperus esculentus in the studied area: A. Cultivated on sandy soil; B. Intercropped with okra (Photographs: Abidja 2017)

Table 4. Major production constraints of Cyperus esculentus in the studied area

\begin{tabular}{lc}
\hline Major constraints & $\begin{array}{c}\text { Percentage of } \\
\text { respondents }(\%)\end{array}$ \\
\hline Attack of tubers by earthworms & 53.92 \\
Attack of tubers by termites & 38.05 \\
Attack of leaves by locusts & 17.69 \\
Attack of leaves by ants & 3.53 \\
Attack of leaves by insects (unknown) & 7.07 \\
\hline
\end{tabular}

\section{The uses of $C$. esculentus}

Cyperus esculentus was produced for food, commercial, medicinal and soil fertilization purposes in the study area. Table 5 shows the importance of these different types of use as well as the organ used, their forms and mode of use. C. esculentus was mainly grown for local consumption. Commercially, C. esculentus tubers are sold fresh or dried. The majority of producers sell these tubers in wholesale and retail either at the market or at home. After harvest, the dry leaves of $C$. esculentus are buried in the soil as fertilizer. In addition, dry or fresh leaves are used as fodder for cattle.
In Atacora Department, only the tuber of C. esculentus entered in the human diet and could be eaten in different forms. The tubers were eaten raw, dry and roasted. According to the producers surveyed, obtaining its forms required certain post-harvest technological operations. After harvest, tubers are washed and dried for five to seven days before becoming sweet. In addition, some Ditmmari farmers/consumers roast the tubers after drying before eating.

According to farmers (16.81\% of the respondents), $C$. esculentus has certain medicinal values. Its tubers are used to treat sexual weakness $(10.61 \%$ of the respondents $)$ and diarrhea $(0.88 \%$ of the respondents). In the case of sexual weakness (aphrodisiac use), fresh or dried tubers are dipped in a traditional alcoholic drink called "Sodabi" for about 3 to 5 days. Then, the patient begins to take a drink of this alcohol a day until healing. For some, dry tubers can be crushed and mixed with the porridge before drinking each day. Tubers are also perforated, tied with a rope and attached to the children's hips to protect them against vomiting (5.32\% of respondents). 


\section{Discussion}

Diversity of Cyperus esculentus landraces

In this study, the folk classification of C. esculentus diversity was mainly based on tuber's morphological traits like several previous studies (Oladele and Aina 2007; Bado et al. 2015; Bori et al. 2018). In our study area, producers classified $C$. esculentus landraces based on tuber's color, which is similar to producers in Burkina Faso (Bado et al. 2015) but contrary to Niger's producers based on tuber's size (Bori et al. 2018). Three landrace types of $C$. esculentus were recorded in our study area which produced light yellow, brown yellow and black tubers. There are also reports by Oladele and Aina (2007) the same types of tigernut landrace in Nigeria. Bado et al. (2015) found three morphotypes of C. esculentus, two producing yellow tubers while the other produces black tubers. Others authors had collected two phenotypes of $C$. esculentus such as yellow and black during biodiesel potentials analysis of species in Benin (Sidohounde et al. 2019), yellow and brown for characterization of its oil extracted in Nigeria (Warra et al. 2017). Different origins (Togo, Burkina Faso and Niger) also produce C. esculentus (Bado et al. 2015; Bori et al. 2018; Follak et al. 2016) and they are adjacent countries of Benin. C. esculentus landraces in this study are likely originated from these countries to Benin through selling or others ways.

\section{Choice of Cyperus esculentus landraces and their distribution}

The choice of landrace type cultivated followed the producer's preference criteria, leading to a variation in the number of landrace types across districts and ethnic groups. In fact, Toucountouna producers cultivated all three landrace types while Tanguiéta producers didn't cultivate the light-yellow type and those of Boukombé didn't cultivate the light yellow and black types.

We noted that the yellow-brown type was produced in all three districts and recognized by producers as a very important landrace type in focus groups surveys. This landrace type was well valued in the market with financial profitability that can exceed the other two landrace types. This would be due to its rapid growth and high yield. In contrast, the respondents said that the light-yellow type had a generally low yield which was likely due to its inflorescence. According to the focus groups, the physiological traits of this landrace type differs instinctively from that of the other two. It is the only landrace type with a relatively short cycle due to the early appearance of its inflorescences. In China, a study by $\mathrm{Hu}$ (2005) showed that early inflorescence reduces the development of the species and then hinders its tuber development. Therefore, the early appearance of inflorescence would be the cause of the low yield found by the producers in the study area; hence, it is neglected by a lot of producers. Nevertheless, some farmers continue to produce this landrace type because of its others uses.

In addition, the producers explained in the focus groups that the black landrace type does not attract traders because of the steady price and risk of financial losses. This would be due to its very low sweet taste and less appreciated compared to other two landrace varieties. This typical taste is indicated by the low sugar content (Oladele and Aina 2007). Our results are in accordance with a study by Follak et al. (2016) who reported that yellow and brown varieties of $C$. esculentus were more available in Nigeria's market contrary to black variety. Maduka and Ire (2019) also reported that the yellow variety of $C$. esculentus tubers looks bigger and has a more attractive color than the brown and black variety.

Concerning species distribution across ethnic groups, Aaama was the only ethnic group that cultivated all three landrace types of $C$. esculentus. The other ethnic groups cultivated only one or two types. This could be explained by the knowledge degree of different ethnic groups on the species. According to group interviews, the producers from Waama ethnic group held better indigenous knowledge of the species than the others. They were the first to have started the cultivation of the species. All other ethnic groups learned the cultivation techniques and management of this species with them.

Table 5. Variety of uses Cyperus esculentus in the studied area

\begin{tabular}{|c|c|c|c|c|}
\hline Types of uses & Organ & Use/disease treated & Form of use & Mode of use \\
\hline Alimentary $(100 \%)$ & Tuber & & Raw, dry and grilled & Eat the tuber \\
\hline \multirow[t]{4}{*}{ Medicinal $(16.81 \%)$} & Tuber & Sexual weakness & Raw and dry & $\begin{array}{l}\text { Soak in the alcohol "Sodabi" and take a drink per } \\
\text { day }\end{array}$ \\
\hline & & & Dry & Crush, put in the porridge and drink \\
\hline & & Diarrhea & Raw and dry & Eat the tuber \\
\hline & & Vomiting of children & Dry & $\begin{array}{l}\text { Rip the dry tubers and string with a rope and tie } \\
\text { on the hip of the children }\end{array}$ \\
\hline Commercial $(88.50 \%)$ & Tuber & & Raw and dry & Sell in wholesale and retail \\
\hline Fertilizer $(3.53 \%)$ & Leaf & & Dry & Bury in the ground \\
\hline
\end{tabular}




\section{Agricultural practices and production constraints}

According to the results obtained, C. esculentus was grown on sandy soil which would facilitate the harvest. These results are consistent with those obtained in Niger by Wourama et al. (2013) who showed that the cultivation area of $C$. esculentus had flat topography and sandy soils. Despite its potential, the area cultivated for $C$. esculentus remains limited in extent in Benin. This shows the low involvement of the populations in the species cultivation in the country, particularly in the northern part, and therefore justifies its neglected and underutilized state in this country (Dansi et al. 2012). This current state of C. esculentus in the country would depend on several production constraints listed by producers in the present study. The major constraints that slow the production of $C$. esculentus were the lack of markets for sale, earthworms and insects attacks. Similar results are also reported by Bori et al. (2018) in Nigeria. Besides, several people continue to consider the species as an invasive species (Bello et al. 2013).

\section{Traditional uses of Cyperus esculentus}

Our investigation revealed that $C$. esculentus was produced for several uses such as food, commercial, medicine, and soils fertilizer. Previous studies also identified these various uses (Oladele et al. 2007; Adejuyitan 2011; Bori et al. 2018; Atawodi et al. 2017). In fact, the most common uses of $C$. esculentus in the study area were for food and tubers selling. Local populations consumed tubers of the species generally in three forms: raw, dried, and roasted. In Nigeria, similar uses were also observed (Oladele and Aina 2007; Sanchez and al. 2012; Gambo and Da'u 2014; Bori et al. 2018). The great food preference of the landrace populations could be explained by the nutritive richness of the species (Ban-Koffi et al. 2005). Besides, the results showed that species tubers were sold and then constituted a great income for producers (Bori et al. 2018). Likewise, Bamishaiye et al. (2011) reported that $C$. esculentus contributes significantly towards improving people's economy and cultural life in rural communities in Sub-Saharan Africa. Finally, some respondents used the species for medicinal purposes, such as to treat sexual weakness, diarrhea and vomiting of children. Similarly, C. esculentus has been mentioned among the medicinal plants sold in the Abomey-Calavi market (Adomou et al. 2012). Adejuyitan (2011) also showed that the species is used in the treatment of diarrhea and sexual infertility. Others authors had reported $C$. esculentus as a very good aphrodisiac plant (Singh et al. 2018; Atoigwe-Ogeyemhe al. 2018).

Study implication for the conservation of Cyperus esculentus

The present study has several implications for $C$. esculentus conservation in Benin. The result showed that black landrace was less diversified in the study area and still cultivated in relatively small areas. As such, several conservation efforts are needed both in situ and ex-situ to maintain species diversity. This study also provides insights regarding the constraints that slowed down the production of tigernut. The problems identified here can serve as reference for scientists to innovate in order to increase the diversity and production of species. Also, there is a different view regarding $C$. esculentus which is considered an invasive species (Bello et al. 2013), suggesting that the utilization of this species might be a strategy to change the opinion.

In conclusion, the present study investigated varietal diversity, local classification and traditional uses of $C$. esculentus in Atacora Department, Benin. It revealed three types of landraces of $C$. esculentus distinguishable through the skin color of the tubers. The cultivation of the species was still neglected because not only were the areas planted by producers low, but it was also little used. In the study area, it is mainly grown for self-consumption and sold in the market.

\section{ACKNOWLEDGEMENTS}

This study was carried out as part of the License's Degree in Biotechnology, Plant Breeding and Seed Production (BAPROS) obtained at the Faculty of Science and Technology (FAST DASSA) of the National University of Sciences, Technologies, Engineering and Mathematics (UNSTIM ABOMEY) through the theme "Diversity of landrace varieties, cultural practices and traditional uses of yellow nutsedge (Cyperus esculentus L.), a neglected and underutilized tuber species in Benin". We express our gratitude to all people who have contributed at various levels to the achievement of this work, particularly all the producers and heads of villages visited during the surveys for the warm welcome they have given us.

\section{REFERENCES}

Abidja S. 2017. Diversité de variétés locales, pratiques culturales et utilisations traditionnelles du souchet comestible (Cyperus esculentus L., une espèce de tubercule négligée et sous utilisée au Bénin. Mémoire de Licence FAST/UNSTIM. [French]

Adejuyitan JA. 2011. Tigernut processing: its food uses and health benefits. Am J Food Technol 6 (3): 197-201. DOI: 10.3923/ajft.2011.197.201

Adomou AC, Yedomonhan H, Djossa B, Legba SI, Oumorou M, Akoegninou A. 2012. Étude Ethnobotanique des plantes médicinales vendues dans le marché d'Abomey-Calavi au Bénin. Int J Biol Chem Sci 6 (2): 745-772. DOI: 10.4314/ijbcs.v6i2.18 [French]

Akoègninou A, Van der Burg WJ. Van der Maesen LJG. 2006. Flore analytique du Bénin (No. 06.2). Backhuys Publishers.

Almou MA. 2008. Exploitation du Cyperus esculentus (souchet): enjeux économiques et impact environnemental dans la région de Maradi.

Ambarwati A, Sembiring L, Yuwono T, Wahyuono S, Moeljopawiro S. 2019. Antimicrobial activities and phylogenetic study of bacteria associated with Cyperus rotundus rhizosphere from Cemoro Sewu Plateau, Indonesia in Biodiversitas 20 (8) : 2206-2212. DOI: 10.13057/biodiv/d200814.

Atawodi SE, Adejo GO, Olowoniyi OD, Liman ML. 2017. Biological, pharmacognostic and phytochemical review of some cultivated medicinal plants of Nigeria. Medicinal and Aromatic Plants of the World-Africa. Springer, Dordrecht. DOI: 10.1007/978-94-024-1120$1 \_12$.

Atoigwe-Ogeyemhe BE, Odigie EB, Achukwu PU. 2018. Aqueous extract of Cyperus esculentus L. (Cyperaceae) enhances libido and spermatogenesis in male Wistar rats. Trop J Nat Prod Res 2 (11): 471475. DOI: $10.26538 / \mathrm{tjnpr} / \mathrm{v} 2 \mathrm{i} 11.2$ 
Bado S, Bazongo P, Son G, Kyaw MT, Forster BP, Nielen S, Bassolé IHN. 2015. Physicochemical characteristics and composition of three morphotypes of Cyperus esculentus tubers and tuber oils. J Anal Methods Chem. DOI: 10.1155/2015/673547

Bamishaiye EI, Bamishaiye OM. 2011. Tiger nut: As a plant, its derivatives and benefits. Afr J Food Agric Nutr Dev 11 (5): 5157 5170. DOI: 10.4314/ajfand.v11i5.70443

Ban-Koffi L, Nemlin GJ, Le Fevre S, Kamenan A. 2005. Caractérisation physico-chimique et potentialités thérapeutiques du pois sucré (Cyperus esculentus L. (Cyperaceae)). Agron Afr 17 (1): 63-71. 10.4314/aga.v17i1.1658 [French]

Bello S, Ahanchédé A, Gbèhounou G, Amadji G, Aho N. 2013. Diversité floristique, ethnobotanique et taxonomie locale des mauvaises herbes de $1^{\prime}$ oignon au nord-est du bénin. Tropicultura 31 (2): 143-152. [French]

Bori H, Karim TDA, Mairo MD, Adam A. 2018. La culture de souchet (Cyperus esculentus) au Niger: Origine, atouts et contraintes. J Anim Plant Sci 37 (1): 5997-6007. [French]

Core Team R. 2017. R: A language and environment for statistical computing. Vienna, Austria.

Dansi A, Vodouhè R, Azokpota P, Yedomonhan H, Assogba P, Adjatin A, Akpagana K. 2012. Diversity of the neglected and underutilized crop species of importance in Benin. Sci World J. DOI: $10.1100 / 2012 / 932947$

Dodet M. 2006. Diversité génétique et phénologie de Cyperus esculentus L. (Cyperaceae) pour une gestion intégrée de l'espèce dans les cultures de Haute Lande. [Dissertation], Université de Bourgogne. [French]

Follak S, Belz R, Bohren C, De Castro O, Del Guacchio E, Pascual-Seva N, Essl F. 2016. Biological flora of Central Europe: Cyperu esculentus L. Perspect Plant Ecol Evol Syst 23, 33-51. DOI: 10.1016/j.ppees.2016.09.003

Gambo A, Da'u A. 2014. Tiger nut (Cyperus esculentus): composition, products, uses and health benefits-a review. Bayero J Pure Appl Sci 7 (1): 56-61. DOI: 10.4314/bajopas.v7i1.11

Gbèmavo DSJC. 2014. Caractérisation Ethnobotanique et Modélisation de la Dynamique de Production du Pourghère (Jatropha curcas L.) au Bénin (Afrique de l'Ouest). [Thèse de doctorat unique] Ecole Doctorale de la Faculté des Sciences Agronomiques (ED/FSA), Université d'Abomey-Calavi (UAC), Bénin. [French]

Hochstrasser ML, Doudna JA. 2015. Cutting it close: CRISPR-associated endoribonuclease structure and function. TiBS 40 (1): 58-66. DOI: 10.1016/j.tibs.2014.10.007

INSAE. 2016a. Cahier des villages et quartiers de ville du département de l'Atacora. [French]

INSAE. 2016b. Effectifs de la population des villages et quartiers de ville du Bénin (RGPH-4, 2013). [French]
Jansen LL. 1971. Morphology and photoperiodic responses of yellow nutsedge. Weed Sci 19 (3): 210-219. DOI : $10.1017 / \mathrm{S} 0043174500048736$

Laly J, Gbemavo DSJC, Gbaguidi AA, Dossou-Aminon I, Dansi A. 2019. Dioscorea dumetorum (Kunth) Pax, a neglected and underutilized yam species in Benin: folk classification and post-harvest conservation. Genet Resour Crop Evol 66 (4): 965-979. DOI: 10.1007/s10722-019-00762-0

Lorougnon G. 1969. Etude morphologique et C. esculentus L. (Cyperacées). Cah. ORSTOM,sér. Biol., n¹0-décembre. [French]

Maduka N, Ire FS. 2019. A review of some prevention strategies against contamination of Cyperus esculentus and tigernut-derived products of economic importance. Asian J Adv Res Rep 1-13. DOI: 10.9734/ajarr/2019/v3i129792

Maduka N, Ire FS. 2018. Tigernut plant and useful application of tigernut tubers (Cyperus esculentus)-A review. CJAST 29 (3): 1-23. DOI: 10.9734/CJAST/2018/43551.

Naderifar M, Goli H, Ghaljaie F. 2017. Snowball sampling: A purposeful method of sampling in qualitative research. Strides Dev Med Educ 14 (3): 1-6. DOI: 10.5812/sdme.67670.

Nurcahyani N, Wirasti Y, Jamsari A, Tjong DH, Kanedi M, 2017. Methanol plant extract of rumput teki (Cyperus rotundus 1.) causing fetal skeleton retardment in mice. Eur J Biomed Pharm Sci 4 (6): 128131.

Oladele AK, Aina JO. 2007. Chemical composition and functional properties of flour produced from two varieties of tigernut (Cyperus esculentus). Afr J Biotechnol 6 (21): 2473-2476. DOI: 10.5897/AJB2007.000-2391.

Sánchez-Zapata E, Fernández-López J, Angel Pérez-Alvarez J. 2012. Tiger nut (Cyperus esculentus) commercialization: Health aspects, composition, properties, and food applications. Compr Rev Food Sci Food Saf 11 (4): 366- 377. DOI: 10.1111/j.1541-4337.2012.00190.x

Sidohounde A, Nonviho G, Bothon FTD, Montcho PS, Dossa CPA, Tchiakpe L, Sohounhloue DCK. 2019. Biodiesel synthesis by ethanolysis of Hura crepitans seed oil unfit for consumption in Benin. Am J Phys Chem 8 (3): 50-57. DOI: 10.11648/j.ajpc.20190803.11.

Singh R, Gupta AK, Kakar S. 2018. Traditional medicinal plants as scientifically proven Aphrodisiacs in IJHBS, 1 (1): 29-36. DOI: https://doi.org/10.46682/ijhbs.1.1.6.

Sodjinou E. 2011. Poultry-Based Intervention as Tool for Poverty Reduction and Gender Empowerment: Empirical Evidence from Benin. [PhD Thesis]. University of Copenhagen, Denmark.

Warouma A, Lawali S, Saadou M. 2013. Institut National des Recherches Agricoles du Bénin (INRAB).

Warra AA, Babatola LJ, Omodolapo AA, Ibraheem BD. 2017. Characterization of oil extracted from two varieties of tiger nut (Cyperus esculentus L.) tubers. Am J Heterocyclic Chem 3 (3): 28-36. DOI: 10.11648/j.ajhc.20170303.12. 